\title{
Intellectual capital management and reporting in European higher education institutions
}

\author{
Yolanda Ramírez Córcoles \\ Universidad de Castilla La Mancha (Spain) \\ Yolanda.Ramirez@uclm.es
}

Received September, 2010

Accepted December, 2012

\section{Abstract}

Purpose: This paper analyses the importance of intellectual capital management as instruments to face the new challenges in European universities. The aim of this paper is to provide assistance initiating universities in the process of developing their ability to identify, measure and manage their intangible assets.

Design/methodology/approach: A review of the most important intellectual capital management initiatives at European universities is shown.

Findings: The experience gained from the case studies provides a basis to understand how European universities are measuring and managing their intellectual capital.

Practical implications: This study helps to define the steps to follow in developing a model of intellectual capital management at universities. In this sense, a necessary starting point would be the definition and diffusion of the organisation's strategic objectives. Then, critical intangibles related to these objectives should be identified and the causal network of relationship among them should be established. Afterwards, a set of indicators is defined and developed for each intangible. Finally, a periodic review of the model to adapt to new challenges should be carried out.

Originality/value: The intellectual capital approach becomes critical at universities, mainly due to the fact that "knowledge" is the main output as well as input in these institutions. Despite its importance, intellectual capital at universities is scarcely dealt 
with in a specific manner. This paper offers practical help to universities to develop means to identify, measure, manage and report on their intangible assets.

Keywords: intellectual capital, management, reporting, Europe, universities

Jel code: 123

\section{Introduction}

Universities in Europe are faced with numerous challenges (Warden, 2003; European Commission, 2003). These include:

- The extended competition with other organisations such as the creation of new public and private universities, the education given by companies through what they call "corporate universities" to contribute to the lifelong learning process of their own employees.

- The increasing level of the internationalization of education and research.

- Pressure to harmonise the different national university systems (e.g. Bologna Process).

- Implementations of new research modes.

- The claims and aspirations of various stakeholders (including industry and society in general).

- Increased demand for transparency and accountability about the "results" and "benefits" derived from the public funds.

To face up these challenges and increase the role of universities in the new knowledge-based economy, it will be necessary to develop intellectual capital models to reach the strategic objectives of universities.

In this context, intellectual capital management become critical at universities, mainly due to the fact that "knowledge" is the main output as well as input in these institutions.

Universities are knowledge producers per se, their most important output is knowledge, incorporated in research results, publications, educated students and productive relationships with their stakeholders. Among their most valuable resources are their researchers, managers and students with their organisational processes and networks of relationships (Warden, 2004). These resources are part of its intellectual capital, and despite its importance, universities seldom deal with them in a specific manner. Up to now, only a few universities have taken the challenge of trying to measure, manage and report on intangibles assets. 
In addition, Universities have continuous external demands for greater information and transparency about the use of public funds (Warden, 2003), and are increasingly provided with greater autonomy regarding their organisation, management, and budget allocation. This situation requires new management and reporting systems: Intellectual capital Management (ICM) is a set of managerial activities aimed at identifying and valuing the knowledge assets of the organisations, leveraging these assets through knowledge sharing, and creating new knowledge (Easterby-Smith \& Lyles, 2003; Holsapple, 2003). They also provide an efficient methodology to identity, measure, manage and diffuse knowledge, that it is to say, a proper way to improve internal management and transparency. This should be translated into greater dynamic, excellence and multidisciplinary in higher education organisations (Elena, 2004). In this line, the work of Ramírez, Santos and Tejada (2012) evidences the appropriateness of the universities incorporate information on intellectual capital in its current accounting information system. Specifically, this study shows a list of the intangible elements on which Spanish universities should provide information in order to satisfy the information needs of its users. However, it is also necessary to develop studies that provide assistance initiating universities in the process of developing a complete model of intellectual capital management at universities.

These new management and reporting systems allow universities to be in a better position to (Warden, 2003):

- Create transparency about the use of public funds.

- Explain the achievements of research, training, innovation and their benefits to stakeholders,

- Illustrate the development of intangible assets,

- Reveal leverage effects and externalities,

- Communicate (new) organisational values,

- Demonstrate their competitiveness.

Taking this initiative forward within their organisations, managers, academics and administrators of universities and research centres will be advantageously placed to promote their organisations' development in the face of increased competition, both from within their respective field, as well as from "new players" in the fields of higher education, research and innovation.

Since there is presently no common international framework for the identification, measurement and disclosure of information on the intangible determinants of corporate value, but only scattered efforts around the world, it seems appropriate to devote efforts to the development of new measurement and management techniques to help universities to identify, 
measure and monitor their intangible sources of value to increase the efficiency and effectiveness of their management.

This paper will analyse the importance of Intellectual Capital Management as instrument to face the new challenges in European universities. We will briefly explore the concept of Intellectual capital in higher education institutions and justify the importance of measuring and managing their intellectual capital in order to improve internal management and to facilitate benchmarking analysis. Our main objective will be to provide assistance initiating universities in the process of developing their ability to identify, measure and manage their intangible assets. According to this, a review of the most important intellectual capital management initiatives at European universities will be shown.

\section{Present situation of European Universities}

Nowadays, European universities are immersed in strong transformation processes (Sorbonne Joint Declaration, 1998; Bologna Declaration, 1999; Prague Declaration, 2001; Communiqué of the Conference of European Ministres Responsible for Higher Education: Berlin (2003) and Bergen (2005)), aim at establishing a European Higher Education Area (EHEA) by the end of the decade (year 2010) and to improve teaching quality level in universities.

On the research front, since 1998 the EU has developed several Framework Programmes in order to boost research cooperation among European countries. In this context, the European Research Area (ERA) is being developed. This project aims at creating the necessary conditions to increase the impact of European research efforts "by strengthening the coherence of research activities and policies conducted in Europe" and "offers a new horizon for scientific and technological activity and for research policy in Europe" (European Commission, 2000: page 3).

These initiatives -EHEA and ERA-imply a new configuration of public education and research system in the EU and requires important efforts to remove barriers and to develop a common framework in the field of research and teaching (Elena, 2004).

In this new context, where knowledge and intellectual capital play a central role in the actual knowledge-based economy, universities become critical elements for the production, transmission and dissemination of knowledge, "due to the key role they play in the three fields of research and exploitation of its results, thanks to industrial cooperation and spin-off; education and training, in particular training of researchers, and regional and local development, to which they can contribute significantly" (European Commission, 2003: page 2). For that reason, the UE considers that "investing more and better in the modernisation and quality of universities is a direct investment in the future of Europe and Europeans" (European Commission, 2005: page 2). 


\section{The term intellectual capital in Universities}

Intellectual capital management become critical at universities mainly due to the fact that universities' main goals are the production and the diffusion of knowledge and their more important investments are in research and human resources (Elena, 2004); so, both inputs and outputs are mainly intangibles.

The term "Intellectual capital" is used to cover all of the non-tangible, or non-physical, assets and resources of an organisation, including its processes, innovation capacity, patents and the tacit knowledge of its members and their network of collaborators and contacts. So, Intellectual capital (IC) has been defined as the combination of intangible resources and activities that "allows an organisation to transform a bundle of material, financial and human resources in a system capable of creating stakeholder value" (European Commission, 2006: page 4).

The Intellectual capital is often represented as consisting of three basic and strongly interrelated components: Human Capital, Structural Capital and Relational Capital (Ramírez, Lorduy \& Rojas, 2007; Cañibano \& Sánchez, 2004; Meritum, 2002; Stewart, 1997; Edvinsson \& Malone, 1997; Euroforum, 1998; CIC, 2002).

In the case of Universities, we could define the components in the following way:

- Human Capital: The set of explicit and tacit knowledge of the Universities personnel (professors, researchers and assistants) acquired through formal and informal educational and actualisation processes embodied in their activities.

- Structural Capital: The explicit knowledge related to the internal process of dissemination, communication and management of scientific and technical knowledge in the organization; it can be both Organizational (the operating environment derived from the interplay between research, management and organisation processes, technology and culture) and Technological (patents, licenses, proprietary software, databases and so on).

- Relational Capital: It gathers the wide set of economical, political and institutional relationships developed and maintained by Universities.

However, Intellectual capital is more than simply the sum of these three elements, "it is about how to let the knowledge of a firm work for it and have it create value" (Roberts, 1999). It is able to generate an increase on the value of a company, and their purpose is to allow a given company to take advantage of opportunities better than competitors and giving rise to the generation of future profits. 
Also, Warden (2003) proposes another component:

- Cultural capital: This component (either within Structural capital or separately in its own right) considers organizational culture as a specific component of IC because of the importance and strength of the Cultural Capital in many Universities and Research Organizations, mainly traditional ones. An organisation can have an "innovative" or "entrepreneurial" culture, or one of "trusting and sharing" and these are potentially "enablers" of great value. However, contradictions between an organisation's structure and its culture, or between its Mission Statement and Strategic Objectives and the dominating academic culture, in some or all of its Faculties, can be just the opposite. Experienced managers of IC and Change Management Programmes are well aware of the need to address these issues before trying to implement new procedures and technologies.

\section{Intellectual Capital Management Studies in European Universities}

Intellectual capital management models provide an efficient methodology to identify, measure, manage and spread knowledge (intangibles); that it is to say, a proper way to improve internal management and transparency at universities.

In that sense, different European universities are starting to manage their Intellectual capital. Some interesting experiences are:

- Observatory of European Universities.

- Intellectual Capital Reports in Austrian Universities.

- PCI Program: Comunidad de Madrid (Spain).

- The Poznan University of Economics Intellectual Capital Report 2005 (Poland)

\section{Observatory of the European University (June 2004-December 2006)}

The «Observatory of the European University» (OEU), created in June 2004, is a project developed within the European "Network of Excellence" PRIME (Policies For Research And Innovation In The Move Towards European Research Area) involving the cooperation of 15 European universities.

The «Observatory of the European University» project capitalises on existing knowledge to develop (with the participating universities):

- A common framework for the characterisation of research activities undertaken in universities.

- An experiment in gathering data under different institutional conditions. 
One of the aims of the OEU is to understand better the importance of managing intangibles in public universities in order to improve their level of quality and competitiveness. Its overall objective is to provide universities with adequate tools for the governance of their research activities. For this purpose, the "Observatory of the European University" will initially develop procedures for data collection in order to, subsequently, produce indicators for universities' strategy and management procedures. This will require discussing and testing new indicators of university performance and activity, as well as finding methods for the representation and measurement of the multidimensional aspects of performance. The final objective is to provide universities with a benchmark for comparisons with similar universities thanks to the development of a platform of quantitative data at the university-level across Europe.

The OEU research team has developed a framework for the characterization of research activities undertaken by universities: the Strategic Matrix. This two-dimensional matrix facilitates the analysis of the university research management and helps to characterize the status of university research management, to identify the best performing universities and to compare the setting in which the universities operate.

The first dimension of the matrix deals with thematic aspects of university research management. The "Thematic Aspects" selected are:

- Funding: which includes all budget elements, both revenues and expenses.

- Human Resources: which includes researchers, research staff and PhDs.

- Academic Outcomes: which includes articles and non articles, academic publications, and the knowledge embodied in PhDs being trained through research.

- Third Mission: which includes the relations linked between university and its nonacademic partners: industry, public authorities and public at large.

- Governance: which includes the process by which the university converts its inputs (funding and human resources) into research outputs (Academic Outcomes and third mission)

The second dimension of the matrix deals with transversal issues which cross these thematic categories. The "Transversal Issues" considered are:

- Autonomy: The university margin of manoeuvre, formally defined as the limits, exogenously established, to which a university must conform.

- Strategic Capabilities: Real university ability to implement its strategic choices.

- Attractiveness: University capacity to attract resources (money, people, equipment, collaboration, etc.) within a context of scarcity. 
- Differentiation Profile: Main features of an university which distinguish this institution from the other strategic actors, mainly universities but also other public research organizations.

- Territorial Embedding: Geographical distribution of university involvements, contacts, collaborations, etc.

A few Key Questions were selected for each cell of the "OEU strategic matrix" (labelled $\mathrm{KQ}$ i.j4). For each one was proposed a few relevant indicators and possible schemes for collecting the data required for these indicators (see figure 1 ).

This common and coherent framework is the first step to identify, manage and publish information about knowledge and intellectual capital in European universities. This consistent framework would make possible to manage knowledge in universities with a battery of comparable indicators.

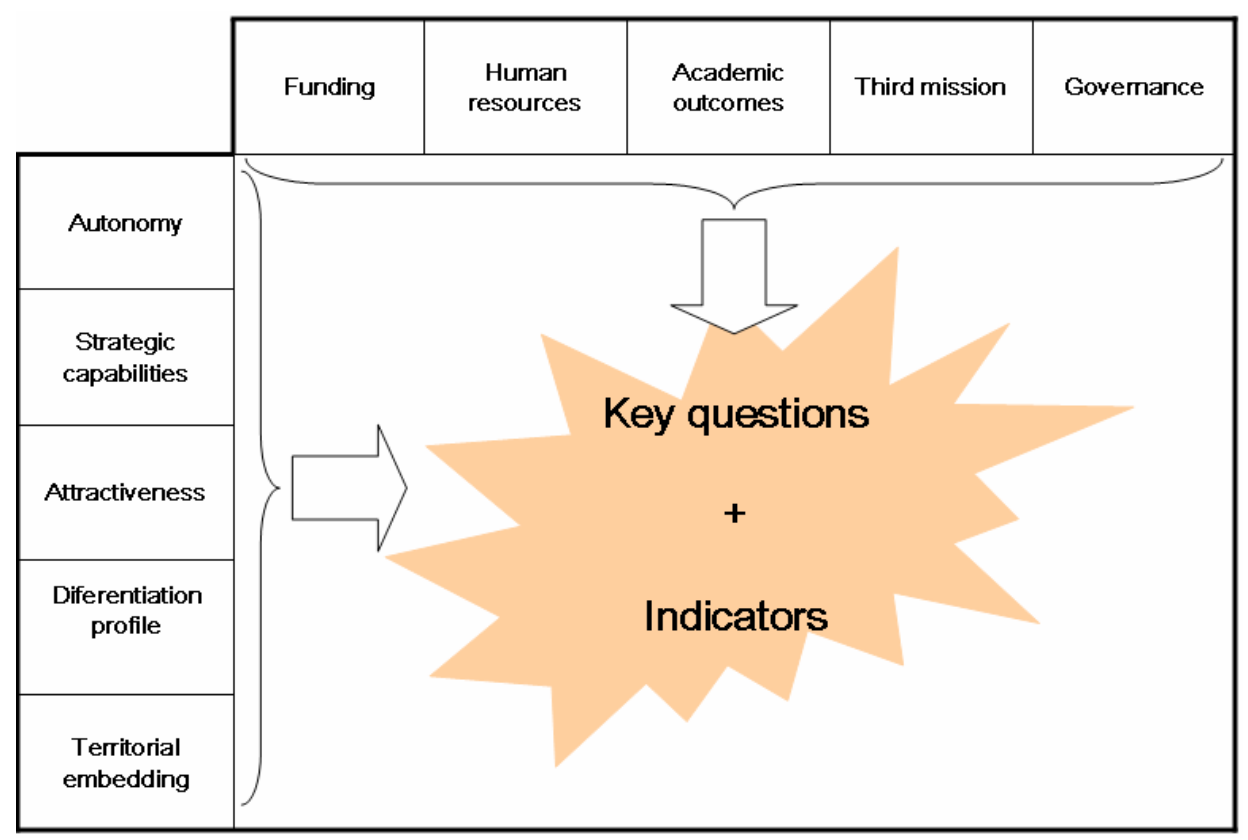

Figure 1. OEU Strategic Matrix (Observatory of the European University, 2005)

Sánchez and Elena (2005) consider that the approach taken in OEU until the moment is completely valid from the analytic point of view, but a higher impact and usefulness can be achieved by using IC terminology. So, these "Thematic Aspects" could be readily assimilated to the categorisation of the Intellectual capital: human, structural and relational capital. Human Capital includes aspect 2, "human resources"; Structural Capital are composed by "funding" and "academic outcomes"; and, finally, Relational Capital is assimilated with "third mission" (Elena, 2004). 


\section{Intellectual capital reports in Austrian Universities}

Austrian public universities are the first higher education institutions in the world that are obliged to produce and diffuse Intellectual Capital Reports (called Wissensbilanz). The intellectual capital report aims at evaluating the intangible assets of each university. Furthermore, some of its numerical indicators are important measures for the allocation of the formula-based budget, it is applied as one basis for the basic budget and also might be used for internal control and external communication (Altenburger and Schaffhauser-Linzatti, 2006b).

The structure and the design of the intellectual capital report are regulated by the intellectual capital report order (Federal Ministry of Education, Science and Culture, 2006). The Austrian University Organisation and Studies Act (further: Universities Act, 2002), in section 13, subsection 6, established the obligation and the general framework for developing this report. By doing so, the Austrian Ministry for Education, Science and Culture recognizes that the "the efficient use of intellectual capital is essential for universities' performance" (Leitner, Schaffhauser-Linzatti, Stowasser \& Wagner, 2005).

The first comprehensive intellectual capital report was published for the year 2007 and Austrian universities have to submit it annually, following the calendar year (Altenburger \& Schaffhauser-Linzatti, 2006a).

According to the Universities Act 2002, the intellectual capital report mainly contains:

- The university's activities, social goals and self-imposed objectives and strategies

- Its intellectual capital, broken down into human, structural and relationship capital

- The processes set out in the performance agreement, including outputs and impacts.

Each university has to report on its input, output, and performance indicators for teaching, research, and third mission activities. The ICR should be prepared for the whole institution and, probably, for scientific fields. Furthermore, each university is free to publish ICR for other sub-levels, like departments, or faculties (Leitner et al., 2005).

The concept of the Intellectual Capital Report described by the UG 2002 is based on the model which has been developed and applied by the Austrian Research Centers Seibersdorf (ARC), the pioneer research European institution in applying IC models to manage its intangibles and in reporting that information.

The model (see figure 2) starts by considering the contextual conditions of the institution, analysing its strategic objectives and mission, and incorporating the three categories of IC: Human Capital, Structural Capital and Relational capital. The core of the model is the 
performance processes: research, education, training, commercialising of research, and knowledge transfer, that can be enlarged or reduced depending on the university profile (obviously, colleges of art, technological universities or business schools have different configurations and strategic objectives and processes) (Leitner, 2004). Finally, the impact on different stakeholders (academic community, government, industry, etc.) is analysed (Elena, 2007: page 155).

Considering the main mission and activities of higher education institutions, the majority of them will be non-financial, so the descriptive elements become crucial to contextualise and better understand the information provided by the figures.

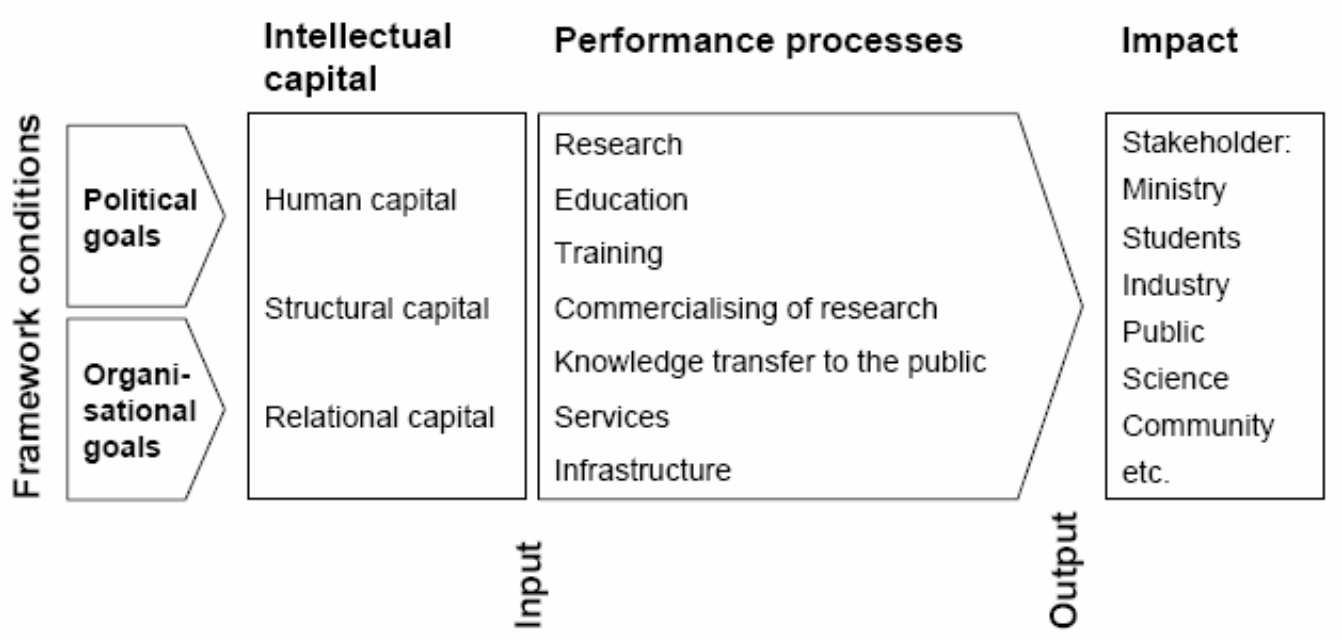

Figure 2. Model IC Reporting for Austrian Universities (Leitner, 2004)

A set of indicators complete the model based on: (a) the set of measures used in the past in Austrian universities; (b) proposed indicators in the intellectual capital literature, and (c) the findings of the evaluation research.

Recently, the Federal Ministry, in collaboration with the Conference of Rectors, has selected the final set of indicators in the Order published in 15th February 2006 (Federal Ministry of Education, Science and Culture, 2006).

The new Order specifies the structure of the ICR, the way of presenting the information and the indicators to be published. It is very extensive and comprises 13 sections and two appendices. The next table summarises the central issues: 


\begin{tabular}{|l|l|}
\hline 13 Sections & $\begin{array}{l}\text { Section 3. The structure of the IC Report } \\
\text { Section 4. List of the nearly all indicators to be published: } 53 \text { indicators } \\
\text { Section 9. List of the remaining indicators: } 7 \text { indicators }\end{array}$ \\
\hline 2 Appendices & $\begin{array}{l}\text { Appendix 1. Definition of indicators } \\
\text { Appendix 2. List of fields of studies }\end{array}$ \\
\hline
\end{tabular}

Table 1. ICR Order: Main Contents (Altenburger \& Schaffhauser-Linzatti, 2006b)

\section{PCI Project (2000-2003) (Intellectual Capital Program): Madrid Region}

This project was carried out by a research group from "Instituto Universitario de Administración de Empresas (Institute for Business Administration) (IADE), belonging to the Autonomous University of Madrid (Spain), and directed by Prof. Eduardo Bueno. They studied the Intellectual capital from the Universities and Public Research Centres (PRCs) in Madrid region.

The investigation was carried out in two separate parts. One of them developed an Intellectual capital Indicators Program applied to the research activity; the other part was a proposition for a knowledge management model applied to the University research and PRCs.

The "Intellectual capital Indicators of the Research Activity and Knowledge Management in the Universities and Public Research Centers (PRCs) of the Madrid Autonomous Region" Program tries to make an inventory of the research capabilities existing within the region in order to improve the allocation of resources. So, the main objective is to know the research capability of Universities and PRCs through an efficient management of their intellectual capital, and how to attain the maximum economic and social return of the resources.

The starting methodological framework was the Intelect Model (Euroforum, 1998), which tries to produce an inventory of intangible elements for the organization and also, it attempts to make a judgment about its ability to create value. The model is arranged in three components, as mentioned above: Human Capital, Structural Capital and Relational Capital, and each one should be measured and managed in such a way that allows a dynamic and evolutionary perspective.

The Board of Indicators was based in the Intelect Model added by other proposals, such as the indicators included in the National Plan for Universities Quality Evaluation. This Board of Indicators proposes an inventory and measurement of the potential and quality of the research results in Universities and PRCs in Madrid Region.

The indicators selected for the research results measurement were organized in three different levels:

- First level indicators. They are expressed in absolute values and offer a global idea of the research effort. 
- Second level indicators. They are relative values or ratios. They express an idea of the existing potential.

- Third level indicators. They are expressed as a percentage in Universities and research centres.

\begin{tabular}{|c|c|c|}
\hline & Universities & Research centres \\
\hline $\begin{array}{l}\text { First level of } \\
\text { indicators }\end{array}$ & $\begin{array}{l}\text { Related to number of meetings and } \\
\text { conferences organized, doctoral programs, } \\
\text { research projects, books and articles, invited } \\
\text { lectures, communications, research visits, } \\
\text { patents, doctoral thesis, awards and } \\
\text { fellowships (etc). }\end{array}$ & $\begin{array}{l}\text { Related to number of meetings and } \\
\text { conferences organized, seminars, agreements } \\
\text { with national and international institutions, } \\
\text { licences, research projects, books and articles, } \\
\text { patents and research awards. }\end{array}$ \\
\hline $\begin{array}{l}\text { Second level of } \\
\text { indicators }\end{array}$ & $\begin{array}{l}\text { N. of books and published articles / Total } \\
\text { number of professors } \\
\text { N. of communications and lectures / Total } \\
\text { number of professors } \\
\text { N. of defended doctoral thesis / Number of } \\
\text { doctoral students } \\
\text { N. of PhDs / Total number of personnel } \\
\text { N. of research visits / Number of research } \\
\text { personnel }\end{array}$ & $\begin{array}{l}\text { N. of Books and published articles / Total staff } \\
\text { N. of patents / Total staff } \\
\text { N. of research awards / Total staff } \\
\text { N. of advisers / Total staff } \\
\text { N. of research staff / Total staff } \\
\text { N. of fellowships / Total staff }\end{array}$ \\
\hline $\begin{array}{l}\text { Third level of } \\
\text { indicators }\end{array}$ & $\begin{array}{l}\% \text { of revenues from Spanish administration } \\
\% \text { of revenues from the EU institutions } \\
\% \text { of revenues from private companies }\end{array}$ & $\begin{array}{l}\% \text { of revenues from Spanish administration } \\
\% \text { of revenues from the EU institutions } \\
\% \text { of revenues from private companies }\end{array}$ \\
\hline
\end{tabular}

Table 2. Generic enumeration of Intellectual capital indicators for the measurement and management of research activities of Madrid Universities and Research Centres. (Bueno, Morcillo \& Rodríguez, 2002)

The three levels of indicators proposed are not organized according to the Intellectual capital categories described. However, the human, structural and relational components are implicitly included in the indicators.

Afterwards, a Model of Intellectual capital Management is developed considering the Universities and PRCs research activity as the source of creations diffusion and reuse of knowledge. This Model considers the research activity made by these institutions as the result of using the IC, aimed to the estimation of the most important IC variables for the studied organizations. Also, it considers that the research processes are fed by resources (inputs) in order to get results (outputs), and tries to asses the relationships between them, as it is indicated in figure 3. 


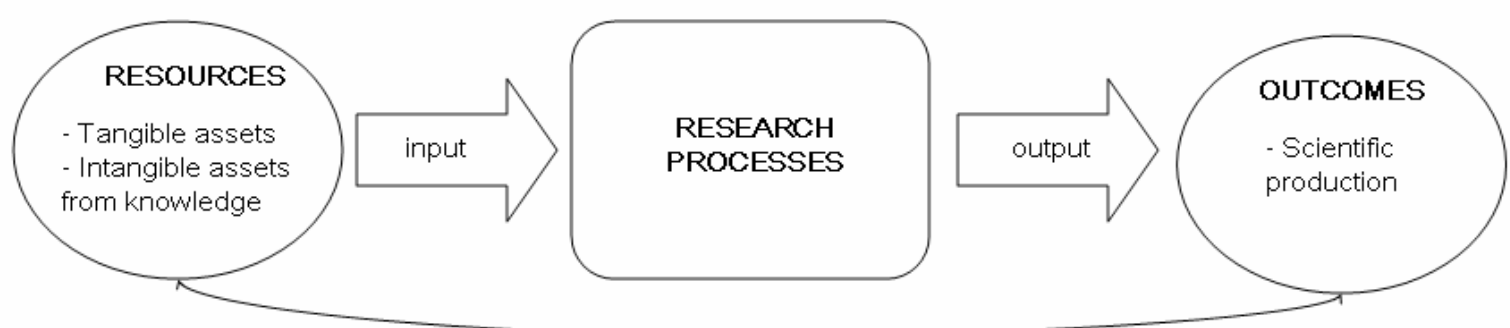

\section{Knowledge processes}

Create and gather knowledge

Distribute and share knowledge

Assimilate and incorporate knowledge

Apply and use knowledge

Reuse and renew Knowledge

Figure 3. Knowledge Leadership and Management Model. Source: (Bueno et al., 2003: page 39)

Specifically, the inputs or resources considered would be the following (figure 4):

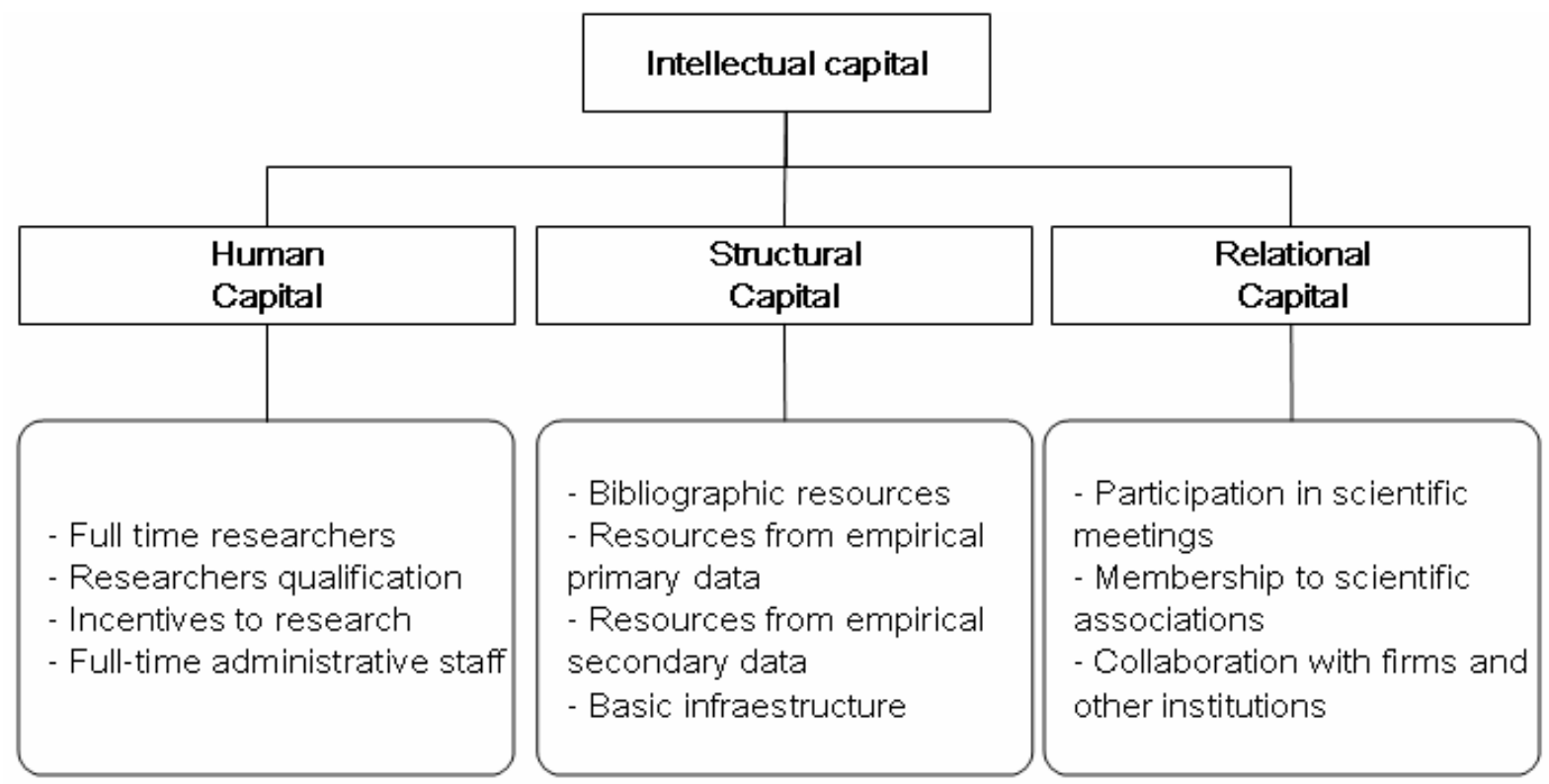

Figure 4. Intellectual capital Structure for research activity in universities and research organisations in the Madrid Community. (Bueno et al. , 2003: page 19)

Universities and PRCs use the resources (inputs), to achieve different research processes (with important differences according to scientific traditions in each knowledge area) to obtain the following results (outputs): 
- Scientific production:

- Books published.

- $\quad$ Articles and book chapters

- Patent rights and any other type of copyright.

- Research projects carried out.

- Lectures and communications at conferences and meetings.

- Social perception of the organization.

- Intellectual capital increase in the organization.

- Research networks established among organizations.

The main objective of the Knowledge Management Model is to establish and the quantitative evaluation of the relationship between inputs and outputs in order to improve the understanding of research processes in Universities and PRCs. In this way, it will be possible to study the improvement in efficiency of those processes (management improvement), so that the model will allow the understanding and management of the inputs of IC, to improve and increment the outputs.

\section{The Poznan University of Economics (Poland)}

Other case is the project "The Poznan University of Economics Intellectual Capital Report 2005" conducted by Fazlagic (2005). This author prepares an intellectual capital report using the framework developed by the Danish Agency for Development of Trade and Industry (2000), which presents intellectual capital in the form of resources, activities and results (see table 3 ).

The activities section of the measurement tool reflects the processes aiming at the renewal and growth of the strategic resources.

Intellectual capital measures should take into account the different qualities of output - the output of the organisation (e.g. publication, a training course), and the output of the client/user (e.g. problem solved). Thus IC measurement looms as an important instigator for increasing the productivity of knowledge-based work. 


\begin{tabular}{|c|c|c|c|}
\hline $\begin{array}{c}\text { Types - } \\
\text { Categories }\end{array}$ & $\begin{array}{l}\text { What is there? } \\
\text { (Resources) }\end{array}$ & $\begin{array}{l}\text { What has been invested? } \\
\text { (Activities) }\end{array}$ & $\begin{array}{c}\text { Which objectives have been } \\
\text { achieved? } \\
\text { (Results) }\end{array}$ \\
\hline Human Capital & $\begin{array}{l}\text { - Number of researchers } \\
\text { - Share of researchers in } \\
\text { total employment } \\
\text { - Average age of a researcher } \\
\text { Women in science (share of } \\
\text { women in workforce) } \\
\text { Inbreeding (share of } \\
\text { researchers who are } \\
\text { graduates of the university) }\end{array}$ & $\begin{array}{l}\text { - Research spending per } \\
\text { employee } \\
\text { - ITC spending per employee } \\
\text { - Time spent in internal } \\
\text { seminars per employee }\end{array}$ & $\begin{array}{l}\text { - Number of newly recruited } \\
\text { staff } \\
\text { - Number of contracts turned } \\
\text { down with regret } \\
\text { - Staff satisfaction } \\
\text { - Staff turnover } \\
\text { - Added value per employee } \\
\text { - Composite employee } \\
\text { - } \text { satisfaction index } \\
\text { publication per researcher }\end{array}$ \\
\hline Structural Capital & $\begin{array}{l}\text { - Share of women occupying } \\
\text { managerial positions } \\
\text { - Number of chairs } \\
\text { (departments) } \\
\text { - Average employment in a } \\
\text { chair (department) } \\
\text { - No of PC per employee }\end{array}$ & $\begin{array}{l}\text { - Total investment in research } \\
\text { infrastructure } \\
\text { - Success ratio in project } \\
\text { acquisition } \\
\text { - Research spending per chair } \\
\text { (department) } \\
\text { - Participation in international } \\
\text { conferences } \\
\text { - (No of conferences } \\
\text { attended, no of researchers } \\
\text { attending conferences) } \\
\text { - No of research projects } \\
\text { underway (including EU } \\
\text { projects) }\end{array}$ & $\begin{array}{l}\text { - No of international students } \\
\text { - Share of international staff } \\
\text { - Name recognition and } \\
\text { reputation (based on press } \\
\text { ranking lists) } \\
\text { - Student satisfaction index } \\
\text { - Number of students } \\
\text { - Number of courses } \\
\text { - Average number of } \\
\text { publications per chair } \\
\text { (department) }\end{array}$ \\
\hline
\end{tabular}

Table 3. IC measurement matrix (Fazlagic, 2005)

As far as the strategic management is concerned, originally it was planned to develop a measurement tool similar to the Balanced Scorecard (BSC) measurement. However, due to the low level of codification of strategic management knowledge at the University, a simpler diagnostic tool was developed (Fazlagic, 2005). It is a self-evaluation chart with a list of thirteen strategic management areas (e.g. mission statement, ISO certification, business education background of the University's top management). Each criterion is self-evaluated on the four-point scale ( $0 \%$ implementation... $100 \%$ implementation).

\section{Conclusions}

The following conclusions can be drawn from the preceding statements:

1. European universities are considered critical to achieve a Europe of Knowledge and for the development of modern societies in general. In line with this, since the end of the last decade, European Universities are dealing with important transformations both in teaching and research activities (Sorbonne Joint Declaration, 1998; Bologna Declaration, 1999; Prague Declaration, 2001; development of a European Higher Education Area (EHEA) and Research Area (ERA)), which imply a new configuration of public education and research system in the EU. These initiatives make European Universities more comparable, increase their level of quality, improve their flexibility, and, basically, result in a more transparent and competitive higher education and research activities. 
2. In this new context, measurement and management of Intellectual capital is a basic task to face the new challenges of European universities. The importance of knowledge management and intellectual capital approaches is mainly due to the fact that the universities' main goals are the production and the diffusion of knowledge and their more important investments are in research and human resources. Thereby, both inputs and outputs are mainly intangibles.

3. However, the need to develop managerial skills in the field of Intellectual capital that universities face is complicated by the great variety of systems and cultures throughout Europe. Likewise, the intellectual assets are specific to each organization, so there is no homogeneous model of Intellectual capital measurement to universities but rather, every university, according to their own specific features and environment must define the best instruments for measurement and management their intangible assets.

4. Intellectual capital analysis is critical for the improvement of internal management and for facilitating benchmarking analysis in European Universities.

5. Different European universities are beginning to manage their Intellectual capital through different models. For instance, Autonomous University of Madrid (Spain) uses the Intelect Model, the Austrian Universities use the ARC model, the Poznan University of Economics uses the model developed by the Danish Agency for Development of Trade and Industry (2000), etc.

6. The experiences on Intellectual capital management in European universities here presented provide ideas on how intangible management processes can be conceptualized in public universities. In this sense, a necessary starting point would be the definition and diffusion of the organisation's strategic objectives. Then, critical intangibles related to these objectives should be identified and the causal network of relationship among them should be established. Afterwards, a set of indicators is defined and developed for each intangible. Finally, a periodic review of the model to adapt to new challenges should be carried out.

7. Institutional commitment becomes essential for the development of Intellectual capital management in universities. 


\section{References}

ALTENBURGER, O.; SCHAFFHAUSER-LINZATTI, M. (2006a). Controlling universities' intellectual capital: are the recently implemented Austrian instruments adequate?. Proceedings of the 2nd Workshop on Visualising, Measuring and Managing Intangibles and Intellectual Capital. Maastricht, The Netherlands.

ALTENBURGER, O.; SCHAFFHAUSER-LINZATTI, M. (2006b). The Order on the intellectual capital reports of Austrian universities - a critical analysis. Proceedings of the 2nd Workshop on Visualising, Measuring and Managing Intangibles and Intellectual Capital. Maastricht, The Netherlands.

BOLOGNA DECLARATION (1999). The European Higher Education Area. Joint Declaration of the European Ministers of Education. Convened in Bologna on the $19^{\text {th }}$ of June 1999.

BUENO, E.; MORCILLO, P.; RODRÍGUEZ, J. (2002). Intellectual capital and Scientific-Production of the Madrid Research Centres. Proceedings of the International Conference "The Transparence Enterprise. The Value of Intangibles". Madrid.

BUENO, E. (Dir.) (2003). Gestión del Conocimiento en Universidades y Organismos públicos de Investigación. Madrid: Dirección General de Investigación, Consejería de Educación, Comunidad de Madrid.

CAÑIBANO, L.; SÁNCHEZ, P. (2004). Measurement, management and Reporting on Intangibles: State of the Art. Accounting and Business Review.

CIC (Knowledge Society Reesearch Centre) (2002). Modelo de medida y gestión del capital intelectual. Pautas para la utilización del Modelo Intellectus. Madrid: CIC-IADE/UAM.

COMUNIQUÉ OF THE CONFERENCE OF EUROPEAN MINISTERS RESPONSIBLE FOR HIGHER EDUCATION (2003). Realising the European Higher Education Area. Berlín.

COMUNIQUÉ OF THE CONFERENCE OF EUROPEAN MINISTERS RESPONSIBLE FOR HIGHER EDUCATION (2005). The European Higher Education Area. Achieving the Goals. Bergen.

DANISH AGENCY FOR DEVELOPMENT OF TRADE AND INDUSTRY (2000). A Guideline for Intellectual Capital Statements - A Key to Knowledge Management. Copenhagen: Danish Trade and Industry Development Council.

EASTERBY-SMITH, M.; LYLES, M. (Eds) (2003). Handbook of Knowledge Management. Oxford: Blackwell Publishing.

EDVINSSON, L.; MALONE, M.S. (1997). Intellectual capital: Realizing your company's true value by finding its hidden brainpower. New York: Harper Business. 
ELENA, S. (2004). Knowledge Management and Intellectual capital in European Universities. Proceedings of the Workshop organised by the Graduate Programme "Entering the Knowledge Society" and the Institute for Science and Technology Studies, Bielefeld University. Germany.

ELENA, S. (2007). Governing the University of the 21st century: Intellectual Capital as a Tool for Strategic Management. Lessons from the European Experience. Ph.D. dissertation. Universidad Autónoma de Madrid.

EUROFORUM (1998). Medición del Capital Intelectual. Madrid: Instituto Universitario Euroforum El Escorial.

EUROPEAN COMMISSION (2000). Making a reality of The European Research Area: Guidelines for EU research activities (2002-2006). Brussels, COM (2000) 612 Final.

EUROPEAN COMMISSION (2003). The role of the Universities in the Europe of Knowledge. Brussels, COM (2003) 58 Final.

EUROPEAN COMMISSION (2005). Mobilising the brainpower of Europe: Enabling universities to make their full contribution to the Lisbon Strategy. Brussels, COM (2005) 152 Final.

EUROPEAN COMMISSION (2006). Ricardis: Reporting intellectual capital to augment research, development and innovation in SMEs. Report to the Commission of the High Level Expert Group on Ricardis. Available at: http://ec.europa.eu/invest-inresearch/pdf/download en/2006-2977 web1.pdf

FAZLAGIC, A. (2005). Measuring the intellectual capital of a University. Proceedings of the Conference on Trends in the Management of Human Resources in Higher Education. Paris. OECD. Available at: http://www.oecd.org/dataoecd/56/16/35322785.pdf

FEDERAL MINISTRY OF EDUCATION, SCIENCE AND CULTURE (2006). Verordnung ueber die Wiessenbilanz (Wissensbilanz-Verordnung-WBV), BGB1, II Nr.63/2006. Available at: http://www.bmbwk.gv.at/universiteeten/recht/gesetze/wbv/wbv.xml

HOLSAPPLE, C.W. (Ed) (2003). Handbook on Knowledge Management. Springer, New York, NY.

LEITNER, K.H. (2004). Intellectual Capital reporting for universities: conceptual background and application for Austrian Universities. Research Evaluation, 13(2): 129-140. http://dx.doi.org/10.3152/147154404781776464

LEITNER, K.H.; SCHAFFHAUSER-LINZATTI, M.; STOWASSER, R.; WAGNER, K. (2005). Data Envelopment Analysis Method for Evaluating Intellectual Capital. Journal of Intellectual Capital, 6(4): 528-543. http://dx.doi.org/10.1108/14691930510628807

MERITUM (2002). Guidelines for Managing and Reporting on Intangibles (Intellectual capital Statements). Madrid: Vodafone Foundation. 
OBSERVATORY OF EUROPEAN UNIVERSITIES (2004). Abstract. May 2004. Available at: http://www.prime-noe.org

OBSERVATORY OF EUROPEAN UNIVERSITIES (2005). Strategic Management for University Research. Second University Panel Session. Madrid: Observatory of the European University. PRAGUE DECLARATION (2001). Towards the European Higher Education Area. Policy and Reform of Higher Education, Inter-University Cooperation, Academic Recognition and Mobility. Prague.

PRIME (2003). Policies for Research And Innovation in the Move Towards the European Research Area. Technical Annex.

RAMÍREZ, Y.; LORDUY, C.; ROJAS, J.A. (2007). Intellectual capital management in Spanish universities. Journal of Intellectual Capital, 8(4): 732-748. http://dx.doi.org/10.1108/14691930710830873

RAMÍREZ, Y.; SANTOS, J.F.; TEJADA, A. (2012). Demanda de información sobre capital intelectual en las Universidades públicas españolas. Cuadernos de Gestión, 12(1): 83-106. http://dx.doi.org/10.5295/cdg.100240yr

ROBERTS, H. (1999). The Control of Intangibles in the Knowledge-intensive Firm. Proceedings of the $22^{\text {nd }}$ Annual Congress of the European Accounting Association, Bordeaux.

SÁNCHEZ, P.; ELENA, S. (2005). Managing Intellectual capital in Public Universities. The Autonomous University of Madrid Example. Proceedings of the $1^{\text {st }}$ Workshop on Visualising, Measuring, and Managing Intangibles and Intellectual capital. Ferrara (Italy).

SORBONNE JOINT DECLARATION (1998). Joint Declaration on Harmonisation of the Architecture of the European Higher Education System. París.

STEWART, T.A. (1997). Intellectual capital: The wealth of organizations. New York: Doubleday/Currency.

WARDEN, C. (2003). Managing and Reporting Intellectual capital: New Strategic Challenges for HEROs. Helpdesk Bulletin, 8. Available at: http://www.ipr-helpdesk.org/newsletter/8/pdf/EN/N08_EN.pdf

WARDEN, C. (2004). Valuation and Evaluation of Intangibles in Universities and Research Centres. Available at: http://www.earma.org/WG/vimak/vimak.html

(C) Intangible Capital, 2013 (www.intangiblecapital.org)

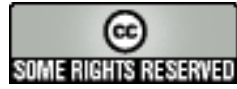

El artículo está con Reconocimiento-NoComercial 3.0 de Creative Commons. Puede copiarlo, distribuirlo y comunicarlo públicamente siempre que cite a su autor y a Intangible Capital. No lo utilice para fines comerciales. La licencia completa se puede consultar en http://creativecommons.org/licenses/by-nc/3.0/es/ 